Original Research Paper

\title{
The Effect of Young Papaya Seed Extract of a Mice Number Spermatozoes (Mus musculus)
}

\author{
Tannya Efritzka Louise Calame ${ }^{1^{*}, \text { Kusmiyati }^{1} \text {, I Wayan Merta }}{ }^{1}$ \\ ${ }^{1}$ Program Studi Pendidikan Biologi, FKIP Universitas Mataram, Indonesia
}

\author{
Article History \\ Received : July 09 ${ }^{\text {th }}, 2021$ \\ Revised : August 30 ${ }^{\text {th }}, 2021$ \\ Accepted : September $15^{\text {th }}, 2021$ \\ Published : September 30 ${ }^{\text {th }}, 2021$ \\ *Corresponding Author: \\ Tannya Efritzka Louise Calame \\ Program Studi Pendidikan \\ Biologi, FKIP Universitas \\ Mataram, Mataram, Indonesia; \\ Email: \\ tannyacalame17@gmail.com
}

\begin{abstract}
Papaya fruit has many benefits, one of which is papaya seed can be used as antifertility drugs especially young papaya seeds. This is because young papaya seeds contain secondary metabolites of alkaloid glycosides and proteolytic enzymes such as papain which can interfere with spermatogenesis. This aims to determine the effect of young papaya seed extract of a mice number spermatozoa. Mice were randomly selected to represent 4 dose groups: control group (P0), extract 30mg/BW (PI), extract $60 \mathrm{mg} / \mathrm{BW}$ (PII) and extract $90 \mathrm{mg} / \mathrm{BW}$ (PIII). Each treatment group was carried out with six repetitions. The treatment was given intravenously by injecting it in the tail of the mice for 15 consecutive days. The observed spermatozoa quality variables is a number of spermatozoa. Data analysis used one way ANOVA significance test $5 \%(\mathrm{p}<0,05)$ and continued with the LSD (Least Significant Difference) $95 \%$ confidence. The result of the study on the quality of spermatozoa showed a significant effect at the doses of $60 \mathrm{mg} / \mathrm{BW}$ (PII) and 90mg/BW (PIII). The higher dose of young papaya seed extract, it increasingly affects the number of sperm. The research concluded that the extract of young papaya seeds has a significant impact of a mice number spermatozoa (Mus musculus).
\end{abstract}

Keywords: Young papaya seeds, number of spermatozoa, mice.

\section{Pendahuluan}

Angka Fertilitas menyebabkan terjadinya penumpukan dan kepadatan penduduk. Kepadatan penduduk ini dapat diatasi dengan sistematis, terarah, dan terukur (Hartanto, 2004). Agar dapat mengatasi pertumbuhan penduduk dibuatlah program Keluarga Berencana (KB) yang bertujuan untuk mengurangi laju pertumbuhan penduduk dengan alat kontrasepsi. Setiadi dan Bachri (2013) menjelaskan bahwa dalam usaha pengendalian penduduk bermacammacam alat serta obat kontrasepsi telah digunakan oleh wanita seperti IUD, pil dan susuk, sedangkan bagi pria terbatas hanya pada penggunaan kondom dan sterilisasi (vasektomi) karena alat kontrasepsi pria masih sedikit jenisnya.

Masyarakat lebih memilih untuk mencari metode kontrasepsi alternatif seperti tumbuhan herbal. Metode alternatif dari sumber tradisional retatif dapat dijangkau oleh harga yang relatif murah, mudah diperolah dan tersedia secara alami, terutama dari keragaman spesies tumbuhan yang memiliki khasiat sebagai alat dan bahan kontrasepsi (Yamin et al, 2018). Contohnya yaitu papaya yang memiliki banyak manfaat. Daunnya dapat digunakan sebagai obatobatan, buahnya dapat dijadikan bahan makanan, sedangkan biji papaya dapat menjadi obat antifertilitas (Katno, 2009).

Program Keluarga Berencana (KB) adalah program nasional untuk mengendalikan pertumbuhan populasi penduduk dari peningkatan angka kelahiran. Namun demikian, fasilitas dan akses masayarakat sangat terbatas dalam memperoleh alat kontrasepsi secara cepat dan mudah. Sebaliknya, secara alamiah cukup tersedia dan telah dikenal luas oleh masyarakat, seperti biji pepaya.

Kandungan papaya adalah senyawa alkaloid baik pada biji papaya tua ataupun biji papaya muda (Udoh, 2009). Sementara itu biji papaya muda memiliki pengaruh yang lebih besar terhadap penurunan kualitas spermatozoa Maka dari itu biji pepaya muda memiliki 
pengaruh yang lebih besar terhadap penurunan kualitas spermatozoa (Raji \& Morakinyo, 2005). Namun, pemanfaatan biji pepaya muda sebagai obat antifertilitas belum banyak dimanfaatkan karena masyarakat belum mengetahui hal ini. Oleh karena itu perlu dilakukan penelitian tentang pengaruh ekstrak biji pepaya muda terhadap jumlah spermatozoa mencit jantan (Mus musculus).

Dari hasil penelitian ini diharapkan dapat memberikan sumber informasi pengetahuan dalam bentuk bukti ilmiah kepada masyarat luas tentang manfaat biji pepaya muda yang dapat dijadikan sebagai obat alternatif kontrasepsi pria.

\section{Bahan dan Metode}

Penelitian eksperimen ini dilaksanakan di Laboratorium Kimia dan Biologi FKIP Universitas Mataram. Obyek penelitian adalah ekstrak biji pepaya muda (Carica papaya) untuk melihat pengaruhnya terhadap kualitas spermatozoa mencit jantan (Mus musculus) dengan Rancangan Acak Lengkap (RAL).

Variabel dalam penelitian ini adalah variabel bebasnya ekstrak biji pepaya muda (Carica papaya), sedangkanvariabel terikatnya adalah kualitas spermatozoa mencit jantan (Mus musculus). Selanjutnya, variabel kontrolnya adalah seperti jenis kelamin, berat badan, usia, jenis makanan, dan jenis mencit (Mus musculus) (Rika Afsari et al, 2016).

Alat-alat yang digunakan yaitu kandang, botol minum mencit, neraca, alat bedah (scalpel, pinset, gunting, jarum), suntikan $1 \mathrm{ml}$, jarum suntik no.24, mikroskop cahaya, hemositometer, oven, tabung maserasi, corong buncher, rotary evaporator, gelas ukur, pipet tetes, cawan petri, sarung tangan, papan seksio, kamera, pengaduk, mortar, pestle, pipet eritrosit, kaca penutup, dan gelas obyek.

Bahan yang digunakan dalam penelitian ini yaitu biji papaya muda yang berumur 3 bulan, makanan mencit (pellet), aquades, etanol $96 \%$, eosin $1 \%$, air, dan $\mathrm{NaCl} 0,9 \%$.

\section{Pembuatan Ekstrak Biji Pepaya Muda}

Biji pepaya muda California dicuci bersih menggunakan air mengalir. Setelah itu dikeringkan. Kemudian dihaluskan sampai berbentuk serbuk kering lalu direndam dengan etanol 96\% selama 72 jam. Cairan disaring menggunakan corong buncher, filtrat di pekatkan dengan menggunakan rotary evaporator dengan suhu $70^{\circ} \mathrm{C}$ sampai pelarut menguap dan terbentuk ekstrak. Kemudian ekstrak biji pepaya tersebut ditimbang sesuai dengan dosis perlakuan yaitu $30 \mathrm{mg} / \mathrm{BB}, 60 \mathrm{mg} / \mathrm{BB}$, dan $90 \mathrm{mg} / \mathrm{BB}$.

\section{Perlakuan}

Hewan percobaan terdiri dari 24 ekor mencit yang dibagi menjadi 4 kelompok, masingmasing kelompok terdiri atas 6 ekor mencit. Dosis pemberian ekstrak biji pepaya pada mencit adalah $30 \mathrm{mg} / \mathrm{grBB}, 60 \mathrm{mg} / \mathrm{grBB}$, dan 90 $\mathrm{mg} / \mathrm{grBB}$. Metode pemberian ekstrak biji pepaya dilakukan dengan cara intravena melalui ekor mencit (Sudarsono, 2003). Semua perlakuan diberikan selama 15 hari. Selanjutnya hewan dikorbankan dengan cara neck dislocation (Erris \& Irma, 2014). Setelah itu sperma diambil dari cauda epididimis untuk diamati spermanya (Wuryanti \& Moeloek, 2000).

\section{Pengamatan Jumlah Spermatozoa}

Sperma diambil pada cauda epididimis mencit, kemudian semen diambil menggunakan pipet eritrosit dengan skala 0,2 lalu ditambahkan larutan $\mathrm{NaCl}$ 0,9\% dan setelah itu dikocok homogen. Larutan semen tersebut diteteskan pada kamar hitung lalu diamati dibawah mikroskop cahaya dan dihitung dengan menggunakan rumus jumlah spermatozoa:

$\mathrm{N}$ x $20 \times 10^{4}$ (Nuraini \& Afifah, 2012).

$\mathrm{N}$ : Jumlah sperma yang dihitung dalam kamar hitung

20 : Faktor pengenceran

$10^{4}$ : Volume kamar hemositometer (Knox, 2012).

Berdasarkan pengamatan tersebut sperma dianggap normal apabila konsentrasi spermatozoa lebih dari 20 juta per $\mathrm{mL}$ semen, dan dianggap infertil apabila konsentrasi sperma kurang dari 20 juta per $\mathrm{mL}$ semen (Dina Fatmawati et al, 2016:157). Dari hasil pengamatan jumlah sperma selanjutnya dianalisis secara statistik. Analisis data dibantu dengan analisis varian (ANOVA) satu arah dengan taraf signifikasi $5 \%(p<0,05)$ untuk mengetahui pengaruh dosis ekstrak biji pepaya muda (Carica papaya) terhadap kualitas spermatozoa mencit jantan (Mus musculus). Jika ada perbedaan akibat dosis yang diberikan, maka 
dilanjutkan dengan uji LSD (Least Significant Difference) dengan taraf kepercayaan $95 \%$.

\section{Hasil dan Pembahasan}

Hasil pengamatan jumlah rata-rata pengaruh ekstrak biji pepaya muda terhadap jumlah spermatozoa mencit jantan (Mus musculus) terdapat pada tabel 1 yang menunjukkan bahwa terdapat dua puluh empat hewan uji dari empat kelompok yang berbeda dan memiliki jumlah rata-rata spermatozoa yang berbeda. Nilai yang ditunjukkan pada tabel 1 dan gambar 1 menunjukkan bahwa keempat hewan perlakuan memiliki jumlah spermatozoa yang berbeda. Sementara itu, pada kelompok kontrol yang diberikan aquades memiliki jumlah rata-rata spermatozoa sebesar 45,6 juta/mL, perlakuan $30 \mathrm{mg} / \mathrm{BB}=46,4 \mathrm{juta} / \mathrm{mL}$, perlakuan $60 \mathrm{mg} / \mathrm{BB}=$ $16 \mathrm{juta} / \mathrm{mL}$, dan perlakuan $90 \mathrm{mg} / \mathrm{BB}=7,1$ juta/mL.Hasil eksperimen ini menunjukan bahwa adanya penurunan jumlah spermatozoa pada pemberian ekstrak biji papaya muda $60 \mathrm{mg} / \mathrm{BB}$ dan 90mg/BB.

Penurunan jumlah spermatozoa ini sesuai dengan penelitian yang dilakukan oleh Christijanti (2009). Selanjutnya, dijelaskan bahwa ekstrak biji pepaya menyebabkan penurunan jumlah spermatozoa tikus jantan setelah diberikan dosis secara oral sebanyak $10 \mathrm{mg} / \mathrm{BB}, 20 \mathrm{mg} / \mathrm{BB}$, dan $40 \mathrm{mg} / \mathrm{BB}$ selama 40 hari. Yang artinya hasil penelitian ini menunjukkan adanya pengaruh ekstrak biji pepaya terhadap jumlah spermatozoa.

\section{Tabel 1. Deskripsi Rata-Rata Jumlah Spermatozoa}

\begin{tabular}{|c|c|c|}
\hline \multicolumn{3}{|c|}{$\begin{array}{c}\text { Deskripsi Pengaruh Ekstrak } \\
\text { Biji Pepaya Muda } \\
\text { terhadapJumlah spermatoza } \\
\text { (juta/mL) }\end{array}$} \\
\hline Perlakuan & $\begin{array}{l}\text { Jumlah } \\
\text { Mencit }\end{array}$ & $\begin{array}{l}\text { Rata- } \\
\text { Rata } \\
\end{array}$ \\
\hline Kontrol & 6 & 45.6 \\
\hline $30 \mathrm{ml}$ & 6 & 46.4 \\
\hline $60 \mathrm{ml}$ & 6 & 16.0 \\
\hline $90 \mathrm{ml}$ & 6 & 7.1 \\
\hline Total & 24 & 28.8 \\
\hline
\end{tabular}

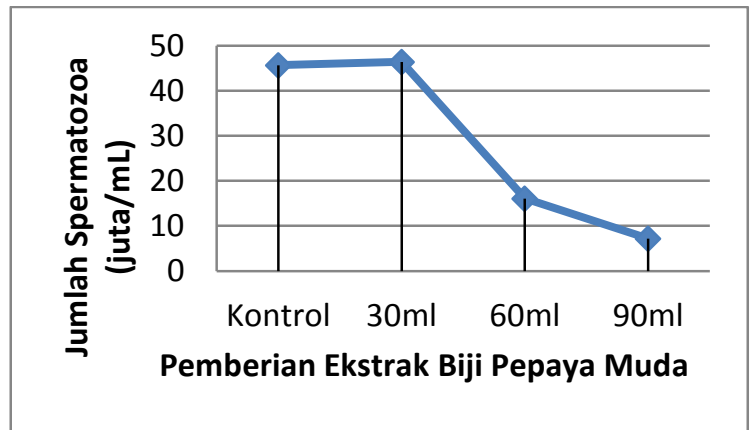

Gambar 1. Grafik Rata-Rata Jumlah Spermatozoa

Hasil analisis One Way Anova (Tabel 2) tentang pengaruh ekstrak biji pepaya muda terhadap jumlah spermatozoa mencit jantan (Mus musculus) pada tingkat signifikansi rata-rata
2446,5 nilai sig $0,000<0,05$ menujukkan ada perbedaan nilai rata-rata jumlah spermatozoa yang signifikan antara keempat perlakuan kelompok mencit jantan (Mus musculus). 
Tabel 2. Deskripsi Uji One Way Anova Rata-Rata Jumlah Spermatozoa

\begin{tabular}{|c|c|c|}
\hline $\begin{array}{c}\text { Uji One Way } \\
\text { Anova } \\
\text { Menggunakan } \\
\text { Program SPSS 26 }\end{array}$ & $\begin{array}{c}\text { Rata- } \\
\text { Rata }\end{array}$ & Sig. \\
\hline & 2446.5 & .000 \\
\hline
\end{tabular}

Sementara itu, hasil uji lanjut dengan uji analisis Least Significance Differences (LSD) tentang pengaruh dari keempat perlakuan yang dibantu dengan SPSS 26 terdapat pada tabel 3.

Tabel 3. Deskripsi Analisis Uji LSD Rata-Rata Jumlah Spermatozoa

\begin{tabular}{|c|c|c|c|}
\hline \multicolumn{4}{|c|}{ Analisis Uji LSD } \\
\hline Ekstrak & Ekstrak & $\begin{array}{c}\text { Rata- } \\
\text { Rata }\end{array}$ & Sig. \\
\hline Kontrol & $30 \mathrm{ml}$ & -.8 & .8 \\
\hline & $60 \mathrm{ml}$ & $29.6^{*}$ & .000 \\
\hline & $90 \mathrm{ml}$ & $38.5^{*}$ & .000 \\
\hline $30 \mathrm{ml}$ & Kontrol & .8 & .8 \\
\hline & $60 \mathrm{ml}$ & $30.3^{*}$ & .000 \\
\hline & $90 \mathrm{ml}$ & $39.2^{*}$ & .000 \\
\hline $60 \mathrm{ml}$ & Kontrol & $-29.6^{*}$ & .000 \\
\hline & $30 \mathrm{ml}$ & $-30.3^{*}$ & .000 \\
\hline & $90 \mathrm{ml}$ & $8.9^{*}$ & .004 \\
\hline $90 \mathrm{ml}$ & Kontrol & $-39.5^{*}$ & .000 \\
\hline & $30 \mathrm{ml}$ & $-39.2^{*}$ & .000 \\
\hline & $60 \mathrm{ml}$ & $-8.9^{*}$ & .004 \\
\hline
\end{tabular}

Tabel 3 menunjukkan uji LSD terhadap jumlah spermatozoa pada mencit jantan (Mus musculus). Berdasarkan tabeldiatas dapat dilihat signifikan jumlah spermatozoa antarakelompok kontrol dengan ekstrak 30mg yaitu 0,8>0,05 artinya Ho diterima yang menyebabkan tidak adanya perbedaan jumlah spermatozoa yang signifikan antara kelompok kontrol dengan ekstrak 30mg. Jadihanya kelompok kontrol dengan kelompok pemberian ekstrak biji pepaya muda 30mg saja yang jumlah spermatozoanya tidak berbeda secara signifikan. Sedangkan ekstrak 60mg dan 90mg jumlah spermatozoanya berbeda secara signifikan.

\section{Pembahasan}

Dari hasil perlakuan pemberian ekstrak biji pepaya muda kepada hewan percobaan dengan dosis yang berbeda-beda didapatkan jumlah spermatozoa yang berbeda pula. Spermatozoa adalah sel yang dihasilkan dari testis yang dikeluarkan melalui penis bersama dengan air mani. Penis adalah alat kelamin luar yang terdiri pangkal, batang dan kepala penis (glans). Bagian ujung dari kepala penis yang ditutupi oleh prepuce (Kusmiyati et al, 2020).

Data hasil pengamatan pada gambar1 dapat dilihat apabila semakin tinggi dosis ekstrak biji pepaya muda yang diberikan kepada hewan percobaan, maka jumlah spermatozoanya semakin menurun secara signifikan. Spermatozoa dianggap infertilpada pemberian ekstrak 60mg dan 90mg Pernyataan ini sesuai dengan teori Fatmawati, bahwa spermatozoa yang jumlahnya kurang dari 20 juta per $\mathrm{mL}$ maka dianggap infertil (FatmawatiDinaet al, 2016).

Kemungkinan penurunan jumlah spermatozoa ini disebabkan oleh senyawa metabolit sekunder alkaloid yang ada di dalam ekstrak biji pepaya tersebut. Pernyataan ini sesuai dengan teori Wiji (2006) yang menyatakan bahwa alkaloid dapat menyebabkan penurunan jumlah sel spermatozoa dikarenakan senyawa alkaloid bersifat kompetitif dan mampu menekan sekresi FSH yang berperan dalam 
merangsang sel sertoli untuk mensekresikan ABP (Androgen Binding Protein) dan berfungsi mengikat testosteron. Mahriani (2008) menambahkan jika FSH terganggu, sel sertoli juga ikut terganggu sehingga menyebabkan penurunan sekresi ABP, akibatnya spermatogenesis menjadi terhambat daan dapat menurunkan kualitas jumlah spermatozoa yang dihasilkan.

Enzim papain juga diduga menjadi penyebab menurunnya kualitas spermatozoa, hal ini juga didukung oleh pernyataan Endang (2003) yang menjelaskan bahwa papain yang ada di dalam ekstrak biji pepaya juga dapat menekan sekresi GnRH. Akibatnya sekresi FSH dan LH menurun dan menyebabkan menurunnya kualitas spermatozoa mencit jantan.

Menurut penelitian yang dilakukan oleh Satriyasa (2008), penurunan kualitas spermatozoa mencit jantan tidak hanya berasal dari senyawa alkaloid dan papain saja, tetapi adanya zat aktif lainnya yaitu seperti senyawa saponin, flavonoid, steroid dan triterpenoid yang ikut berperan dalam mengganggu proses spermatogenesis..

Senyawa lainnya yang diduga ikut berperan dalam menurunkan kualitas spermatozoa adalah flavonoid (Nurliani et al, 2005). Senyawa flavonoid yang ada di dalam ekstrak biji pepaya mampu menginduksi terjadinya apoptosis. Apoptosis merupakan proses kematian secara alami dan terprogram. Apoptosis terjadi ketika sel mengalami kerusakan yang tidak dapat diperbaiki lagi misalnya karena infeksi serius, mengalami stress dan kerusakan DNA akibat adanya radiasi.

Senyawa flavonoid juga bersifat sitotoksik, sehingga dapat menyebabkan berkurangnya jumlah sel spermatozoa. Sitotoksik merupakan suatu senyawa yang dapat menyebabkan kerusakan dan kematian terhadap sel dari makhluk hidup. Senyawa tersebut dapat berasal dari luar tubuh dan dapat berasal dari dalam tubuh itu sendiri. Efek dari sitotoksik tersebut dapat menyebabkan gangguan metabolisme sel sehingga oksigen berkurang dan masuknya senyawa toksik dari dalam ekstrak biji pepaya ke dalam tubuh (Ratna, 2008).

Berdasarkan hasil pengamatan setelah dilakukan 15 hari perlakuan, setelah hari ke-8 penyuntikan terlihat perubahan warna pada ekor mencit yang diberi ekstrak 60mg dan 90mg. Ekor mencit terlihat menghitam dan mengeras. Hal ini kemungkinan disebabkan karena infeksi pada area suntikan,terjadinya pembekuan darah pada ekor dan kemungkinan karena adanya senyawa flavonoid dan alkaloid yang ada di dalam ekstrak biji pepaya yang bersifat sitotoksik. Dan juga kandungan dosis ekstrak yang diberikan sangatlah tinggi, sehingga menyebabkan perubahan warna pada ekor mencit.

Hasil penelitian yang telah dilakukan menunjukan bahwa pemberian ekstrak biji pepaya muda dapat menurunkan kualitas spermatozoa. Dan kelompok perlakuan III merupakan perlakuan paling efektif dalam menurunkan kualitas spermatozoa pada mencit jantan, yaitu dengan pemberian dosis sebesar 90mg/BB. Jadi, berdasarkan penelitian yang telah dilakukan terlihat adanya pengaruh ekstrak biji papaya muda terhadap kualitas spermatozoa mencit jantan secara signifikan.

\section{Kesimpulan}

Berdasarkan penelitian yang telah dilakukan, dapat disimpulkan bahwa ekstrak biji papaya muda (Carica papaya) berpengaruh secara signifikan terhadap kualitas spermatozoa mencit jantan (Mus musculus) yang dapat dilihat dari menurunnya jumlah spermatozoa mencit seiring dengan bertambahnya dosis ekstrak biji pepaya muda yang diberikan. Dosis yang paling efektif dalam menurunkan spermatozoa yaitu sebesar 90mg/BB.

\section{Ucapan Terima Kasih}

Penelitian ini dapat terlaksana dengan baik berkat bantuan dari berbagai pihak, oleh sebab itu peneliti mengucapkan terima kasih kepada Dosen Pembimbing, Pegawai laboratorium, dan teman-teman yang telah membantu.

\section{Referensi}

Afsari, Rika, Kusmiyati \& I Wayan Merta (2016). Pengaruh Pemberian Ekstrak Daun Sirih Merah (Piper crocatum) Terhadap Penurunan Kadar Gula Darah Mencit (Mus musculus). Jurnal Biologi Tropis. $\quad 16 \quad$ (1): 51. DOI:10.29303/JBT.V1611.217 
Bagus, Komang Satriyasa (2008). Fraksi Heksan Ekstrak Biji Pepaya Muda Dapat Menghambat Proses Spermatogenesis Mencit Jantan Lebih Besar Daripada Fraksi Metanol Ekstrak Biji Pepaya Muda. Jurnal Penelitian Juli 2005. Bagian Pharmakologi Ilmu Kedokteran Universitas Udayana Denpasar : Bali. Diakses dari: https://ojs.unud.ac.id/index.php/ijbs/articl e/view/3740

Dina, Fatmawati, Israhnanto Isradji, Iwang Yusuf, \& Suparmi (2016). Kualitas Spermatozoa Mencit Balb/C Jantan Setelah Pemberian Ekstrak Buah Kepel (Stelechocarpus burahol). Jurnal Fakultas Kedokteran Universitas Islam Sultan Agung. 48 (3): 157. Retrieved from: http://dx.doi.org/10.15395/mkb.v48n3.84 $\underline{5}$

Endang, Purwaningsih (2003). Pengaruh Ekstrak Daun Kemuning (Murraya paniculata L.) Terhadap Kualitas Sperma Manusia In Vitro. Jurnal Kedokteran YARSI. 11 (2): 77-84. Diakses dari: http://lontar.ui.ac.id/

Erris \& Irma H. (2014). Pengaruh Kebisingan Terhadap Kuantitas dan Kualitas Spermatozoa Tikus Putih (Rattus norvegicus) Jantan Dewasa. Media Litbangkes. $24 \quad$ (3): $123-128$. DOI:10.22435/mpk.v23i3.3646.123-128

Hartanto (2004). Keluarga Berencana dan Kontrasepsi. Jakarta: Pustaka Sinar Harapan.

Katno (2009). Tingkat Manfaat dan Keamanan Tanaman Obat dan Obat Tradisional. UGM: Balai Penelitian Tanaman Obat Tawamangu. Diakses dari: https://docplayer.info/228505-Tingkatmanfaat-dan-keamanan-tanaman-obatdan-obat-tradisional-katno-1-s-pramono2-abstrak.html

Knox, R.V. (2012). Semen Processing, Extending and Storage For Artificial Insemination In Swine. Department of
Animal Sciences University of Illinois. Diakses dari: https://www.semanticscholar.org/paper/S emen-processing\%2C-extending-\%26storage-for-in-swine \%3A-KnoxKnox/18fda07db13dd76bd068d66b9d938 $\underline{\text { ee470cdc262 }}$

Kusmiyati, Khairuddin, Prapti Sedijani, \& I Wayan Merta (2020). Pengenalan Struktur Fungsi Organ Reproduksi Sebagai Upaya Pencegahan Kekerasan Seksual Pada Anak. Jurnal Pendidikan dan Pengabdian Masyarakat. 3 (3): 185. Diakses dari: http://jurnalfkip.unram.ac.id/index.php/JP $\underline{\mathrm{PM} / \text { article/view/2049 }}$

Mahriani (2008). Kajian Ekspresi Protein Bax pada Gangguan Spermatogenesis Pasca Pemaparan 2,5-hexanadione, pada Tikus Putih (Rattus norvegicus L.). Jurnal Biologi 7 (1) : 1-5. DOI: http://dx.doi.org/10.24843/jbiounud

Nuraini, T., Kusmana \& D.Afifah (2012). Penyuntikan Ekstrak Biji Carica papaya L. Varietas Cibinong pada Macaca fascicularis L. dan Kualitas Spermatozoa serta Kadar HormonTestosteron. Makara Kesehatan. $16 \quad$ (1): $\quad 9-16$. DOI:10.7454/msk.v16i1.1296

Nurliani, Anni Rusmiati \& Santoso, B. Heri. (2005). Perkembangan Sel Spermatogenik Mencit (Mus musculus L.) Setelah Pemberian Ekstrak Kulit Kayu Duarian (Durio zibethinus). Jurnal Penelitian berl. PenelHayati. Universitas Lambung Mangkurat : Banjarmasin Kalimantan Selatan. 11 : 77-79.DOI: http://dx.doi.org/10.23869/bphjbr.11.1.20 $\underline{0513}$

P.B. Udoh (2009). Effect of Caricapryl-99 Seed Alkaloid Extract on The Serum Levels of Sex Hormons and Pituitary Gonadotrophins in Male Albino Rats.Nigerian journal of Physiological Sciences. $\quad 24 \quad$ (1): $13-15$. DOI: $10.4314 /$ njps.v24i1.46375 
Raji, Y., \& Morakinyo, A.O. (2005). Impact of the Chloroform Extract of Carica papaya Seeds on OestrousOycle and Fertility in Female Albino Rats. Nigeria: Departement of Physiology Collage of Medicine Ibadan University. Diakses dari: https://scialert.net/fulltext/?doi=jms.2005. $\underline{337.343}$

Ratna Budhi, Pebrian (2008). Pengaruh Ekstrak Metanolik Daun Kenikir (Cosmos caudatus kunth) terhadap Pemacuan Apoptosis Sel Kanker Payudara. Jurnal Pharmacon. 9 (1): 21-26. Diakses dari:http://etheses.uinmalang.ac.id/576/10 /06520055\%20Daftar\%20Pustaka.

Setiadi, D., \& S. Bachri (2013). Pengaruh Air RebusanAkar Aru (Caesalpinia bonduc) Terhadap Kualitas Sperma Epididimis Mencit (Mus musculus): Dasar Pengembangan Obat Kontrasepsi Tradisional Bagi Laki-Laki. Jurnal Biologi Tropis. 13 (2): 129. Diakses dari: http://dx.doi.org/10.29303/JBT.VI312.14 $\underline{6}$

Sudarsono (2003). Efek Biji Pepaya (Carica papaya L) terhadap Ketebalan Epitel Germinal dan Jarak Tubulus Seminiferi serta Jumlah Sel Spermatogenik pada Stage VII Daur Spermatogenesis. Bandung:Majalah Kedokteran Bandung No. 2 Tahun 2003. Diakses dari: https://digilib.uns.ac.id/dokumen/downloa d/12807/MjczNjA=/Pengaruh-pemberianekstrak-biji-pepaya-carica-papayaperoral-terhadap-jumlah-sel-spermatidmencit-mus-musculus-abstrak.

Wiji, Isni (2006). Pengaruh Filtrat Buah Pepaya (Carica papaya L.) Muda Terhadap Jumlah Spermatozoa.Malang: Jurusan Biologi Fakultas MIPA Universitas Muhammadiyah Malang.

Wulan, Christijanti (2009). Penurunan Jumlah dan Motilitas Spermatozoa Setelah Pemberian Ekstrak Biji Pepaya (Kajian Potensi Biji Pepaya sebagai Bahan Kontrasepsi Alternatif). Jurnal Biosaintifika. 4 (1): 19 26.DOI: $10.15294 /$ biosaintifika.v1i1.38

Wuryantari \& N. Moeloek (2000). Perkembangan Mutakhir Fisiologi Fungsi Testis: dari Organ Sampai Gen. Majalah Kedokteran. 50 (8): 18-23. Diakses dari: https://sinta.unud.ac.id/uploads/wisuda/10 14018203-3-5.\%20BAB\%20II\%20\%20Kajian\%20Pustaka.

Yamin, M., Burhanudin, Jamaluddin \& Nasruddin (2018). Pengobatan dan Obat Tradisional Suku Sasak di Lombok. Jurnal Biologi Tropis. 18 (1): 3. DOI:10.29303/JBT.V1811.463 